\title{
Article
}

\section{The Effect of Chemical Activating Agent on the Properties of Activated Carbon from Sago Waste}

\author{
Octolia Togibasa ${ }^{1, *(1)}$, Mumfaijah Mumfaijah ${ }^{1}$, Yanti Kiding Allo ${ }^{1}$, Khaeriah Dahlan ${ }^{1}$ \\ and Yane Oktovina Ansanay ${ }^{2}$ (D) \\ 1 Physics Study Program, Department of Physics, Universitas Cenderawasih, Jayapura 99358, Indonesia; \\ mumfaijah@gmail.com (M.M.); yantiallo28@gmail.com (Y.K.A.); khaeriahd@gmail.com (K.D.) \\ 2 Geophysical Engineering Study Program, Department of Physics, Universitas Cenderawasih, \\ Jayapura 99358, Indonesia; yane.ansanay@gmail.com \\ * Correspondence: octolia@fmipa.uncen.ac.id
}

check for updates

Citation: Togibasa, O.; Mumfaijah, M.; Allo, Y.K.; Dahlan, K.; Ansanay, Y.O. The Effect of Chemical Activating Agent on the Properties of Activated Carbon from Sago Waste. Appl. Sci. 2021, 11, 11640. https:// doi.org/10.3390/app112411640

Academic Editor: Raed Abu-Reziq

Received: 27 October 2021

Accepted: 3 December 2021

Published: 8 December 2021

Publisher's Note: MDPI stays neutral with regard to jurisdictional claims in published maps and institutional affiliations.

Copyright: (c) 2021 by the authors. Licensee MDPI, Basel, Switzerland. This article is an open access article distributed under the terms and conditions of the Creative Commons Attribution (CC BY) license (https:// creativecommons.org/licenses/by/ $4.0 /)$.

\begin{abstract}
The effect of chemical activators on the properties of activated carbon from sago waste was conducted in this study by using $\mathrm{ZnCl}_{2}, \mathrm{H}_{3} \mathrm{PO}_{4}, \mathrm{KOH}$, and $\mathrm{KMnO}_{4}$ chemical solutions. The carbonized sago waste was added to each chemical solution, boiled at $85^{\circ} \mathrm{C}$ for $4 \mathrm{~h}$, and heated at $600{ }^{\circ} \mathrm{C}$ for $3 \mathrm{~h}$. The porosity, microstructural, proximate, and surface chemistry analyses were carried out using nitrogen adsorption with employing the Brunauer Emmett Teller (BET) method and the Barret-Joyner-Halenda $(\mathrm{BJH})$ calculation, scanning electron microscopy by using energy dispersive spectroscopy, $\mathrm{X}$-ray diffractometer, simultaneous thermogravimetric analysis system, and the Fourier-transform infrared spectroscopy. The results showed that the activated carbon prepared using $\mathrm{ZnCl}_{2}$ acid had the highest specific surface area of $546.61 \mathrm{~m}^{2} / \mathrm{g}$, while the $\mathrm{KOH}$ activating agent surpassed other chemicals in terms of a refined structure and morphology, with the lowest ash content of $10.90 \%$. The surface chemistry study revealed that $\mathrm{ZnCl}_{2}$ and $\mathrm{KOH}$ activated carbon showed phenol and carboxylate groups. Hence, $\mathrm{ZnCl}_{2}$ acid was suggested as activating agents for micropore carbon, while $\mathrm{KOH}$ was favorable to producing a mesopore-activated carbon from sago waste.
\end{abstract}

Keywords: sago waste activated carbon; activating agents; acid treatment; base treatment; porous properties; structural properties; thermal decomposition; surface groups

\section{Introduction}

Activated carbon has an amorphous, fullerene-like structure, with a large and small amount of oxygen and hydrogen, respectively [1]. This structure leads to an increase in its surface area, a high degree of porosity [2,3], and a wide spectrum of oxygenated functional groups $[4,5]$. Activated carbon has attracted attention due to its large application and environmental benefits. Furthermore, the adsorption of heavy metals [6-8], organic compounds [9], dyes [10,11], $\mathrm{CO}_{2}$ capture [2,12,13], catalyst [14,15], ammonia, and methane storage [16-18], were some common applications. The use of activated carbons as materials for electrochemical double-layer capacitors (EDLC) has made them suitable for industrial applications [19-21].

Lignocellulosic precursors and biomass sources were the main raw materials for activated carbon production. However, the need for abundant, renewable, and low-cost raw material, has motivated many studies to explore materials used in production. The studies on activated carbon were the third-highest since 2005, after graphene and carbon nanotubes, related to carbon materials [22]. Several precursors were obtained from biomass, waste, various parts of plants, cotton stalk [6], peanut shell [7], nutshells [9], pineapple waste [11], oil palm shell [17], and coffee beans [19]. In addition, chemical and physical activation are the two most important methods that activate carbonaceous materials [22], though thermal activation [23] and microwave radiation [24] methods have also been reported. Other 
studies summarized several parameters in the manufacture of activated carbon $[22,25,26]$, and chemical activation agent is an important key. These agents include zinc chloride $\left(\mathrm{ZnCl}_{2}\right)$, potassium hydroxide $(\mathrm{KOH})$, phosphoric acid $\left(\mathrm{H}_{3} \mathrm{PO}_{4}\right)$, sulfuric acid $\left(\mathrm{H}_{2} \mathrm{SO}_{4}\right)$, and sodium hydroxide $(\mathrm{NaOH})$. Also, $\mathrm{H}_{2} \mathrm{O}_{2}$ [27], potassium carbonate $\left(\mathrm{K}_{2} \mathrm{CO}_{3}\right)$ [28], $\mathrm{CaCl}_{2}$ [29], $\mathrm{KMnO}_{4}[30,31]$, formamide [32] and other acid salts [33] have been used as activating agents. The high rate of studies on activated carbons mentioned above promotes this study on the effect of activating agents on the properties of activated carbon.

Presently, sago waste is used as a raw material to produce activated carbon. It (Metroxylon sago) is an endemic plant in Indonesia, with approximately 1.2 million ha of sago forest, which is $50 \%$ of the total sago forest in the world. Indonesia has about 219,978 ha of sago starch production area by 2017, with a total production of 489,643 tons [34]. Furthermore, the plant is the main source of carbohydrates for coastal communities in eastern Indonesia, and it is included in local food commodities. On the other hand, behind the high production of sago in Indonesia, its waste causes environmental pollution [35]. However, sago waste is rich in lignocellulosic fibers, namely cellulose $36.2 \%$, hemicellulose $15.18 \%$, and lignin $12.34 \%$ [36,37], making them suitable as activated carbon raw material.

The fabrication of activated carbon using sago as its raw material has been studied previously, either from its waste [31,38-41], palm bark [42,43], or pulp hydrogel [44]. In addition, the activated carbon has been synthesized using several chemical activating agents, which include $\mathrm{H}_{2} \mathrm{SO}_{4}, \mathrm{ZnCl}_{2}, \mathrm{KOH}$, and $\mathrm{KMnO}_{4}$, with a variety of chemical concentrations, activation temperature conditions, and agitation time. However, none of these studies focused on the effect of activator variations. Therefore, this study aims to determine the effect of activators on the properties of activated carbon from sago waste. In this study, $\mathrm{ZnCl}_{2}$ and $\mathrm{H}_{3} \mathrm{PO}_{4}$ were used as a chemical acid activator, while $\mathrm{KOH}$ and $\mathrm{KMnO}_{4}$ as base chemical treatments. Then, the porosity, microstructural, proximate, and surface chemistry analyses helped to understand the properties of the activated carbon from sago waste and its prospective application. In addition, this study also aims to elevate the potentials of sago waste from the local community consumptions to a higher economic value.

\section{Materials and Methods}

\subsection{Material Preparations}

For the purpose of this study, sago waste was extracted from the remains of starch production, traditionally practiced by the community in Maribu Village, Jayapura Regency, Papua Province, Indonesia was used. The chemical solution $\mathrm{KOH}, \mathrm{KMnO}_{4}, \mathrm{ZnCl}_{2}$, and $\mathrm{H}_{3} \mathrm{PO}_{4}$ were used as activating agents, with a concentration of $20 \%(w / v)$ each, and $\mathrm{pH}$ values of 12.1, 9.1, 4.2, and 2.2, respectively. Other supporting materials include $\mathrm{HCl} 1 \mathrm{M}$, distilled water, and filter paper. The main instruments for the activation process consisted of a digital pH sensor (PASCO PS-2102), a test sieve (B-ONE size 100 mesh), a magnetic stirrer (DLAB MS-H280-Pro), an electronic balance (OHAUS SP202 AM), a digital oven (B-ONE OV-45), and a muffle furnace (FNC-7.2).

\subsection{Activated Carbon Fabrication}

The sago waste raw material was washed and dried using clean water and oven, respectively, at $90^{\circ} \mathrm{C}$ for $2 \mathrm{~h}$. Furthermore, the dried precursor was carbonized at $400^{\circ} \mathrm{C}$ for $2 \mathrm{~h}$ using a furnace. The carbon sago waste was crushed and sieved to obtain a fine carbon bulk. Then $5 \mathrm{~g}$ of the prepared carbon waste sago was added to a $25 \mathrm{~mL}$ chemical solution, for each activating agent. The mixed solutions were boiled at $85^{\circ} \mathrm{C}$ for $4 \mathrm{~h}$ to enhance the activation process and then filtered. The precipitate was heated at $600{ }^{\circ} \mathrm{C}$ for $3 \mathrm{~h}$ [45]. Subsequently, the carbon that was activated using acid treatment $\left(\mathrm{ZnCl}_{2}\right.$ and $\left.\mathrm{H}_{3} \mathrm{PO}_{4}\right)$ was repeatedly washed with warm distilled water $\left(70^{\circ} \mathrm{C}\right)$ until a constant $\mathrm{pH}$ of 7 was achieved [41], whereas the carbon that was activated using base treatment $(\mathrm{KOH}$ and $\mathrm{KMnO}_{4}$ ) was added to $3 \mathrm{~mL}$ of $0.1 \mathrm{M} \mathrm{HCl}$ and washed with warm distilled water [46], with repeated washes until a neutral $\mathrm{pH}$ was attained. The samples were dried in an oven at 
$110{ }^{\circ} \mathrm{C}$ for $2 \mathrm{~h}$ to obtain the activated carbon products. In the end, the final products were measured to calculate the yield, by the following equation [45]:

$$
\text { Yield }(\%)=\frac{\text { Final weight of activated carbon }}{\text { Initial weight of dried sago waste }}
$$

\subsection{Activated Carbon Characterization}

The porous characteristic was determined by nitrogen adsorption using Quantachrome Nova 4200e instrument. Also, the Brunauer Emmett Teller (BET) method was used to characterize specific surface areas, together with the Barret-Joyner-Halenda (BJH) calculation to predict the pore volume. The scanning electron microscope (Jeol JSM IT 200) with energy dispersive spectroscopy (EDS) was used to analyze the morphology and the element composition. Meanwhile, the X-ray diffraction (SHIMADZU XRD-7000) systems were used to identify the microcrystalline structure of the samples. Furthermore, the thermal decomposition behavior was investigated by Simultaneous ThermogravimetricDifferential Thermal-Differential Scanning Calorimetry Analysis (TGA-DTA-DSC) using NEXTA STA (Hitachi STA200RV) system. Meanwhile, the Fourier-transform infrared (FTIR) spectroscopy (The PerkinElmer spectrum IR 10.6.1) was used to determine the functional groups in the activated carbon materials.

\section{Results}

\subsection{Porous Properties}

Figure 1 illustrates the effect of the chemical activating agents on the adsorptiondesorption isotherms of activated carbon from sago waste. The activated carbon prepared with acid activating agents $\left(\mathrm{ZnCl}_{2}\right.$ and $\left.\mathrm{H}_{3} \mathrm{PO}_{4}\right)$ indicated a Type I isotherm according to the IUPAC classification [47]. This is evidenced by a sharp increase in nitrogen adsorption at low pressures, followed by a long plateau region at higher pressures, indicating a micro-porosity behavior. However, a narrow hysteresis can be seen due to the existence of mesopores [45]. Conversely, the activated carbon prepared with base treatment $(\mathrm{KOH}$ and $\mathrm{KMnO}_{4}$ ) indicated a Type IV or Type II isotherm with a clear hysteresis at high pressures. Consequently, this indicates a progressive development of mesopores, as well as a distribution of pore sizes.

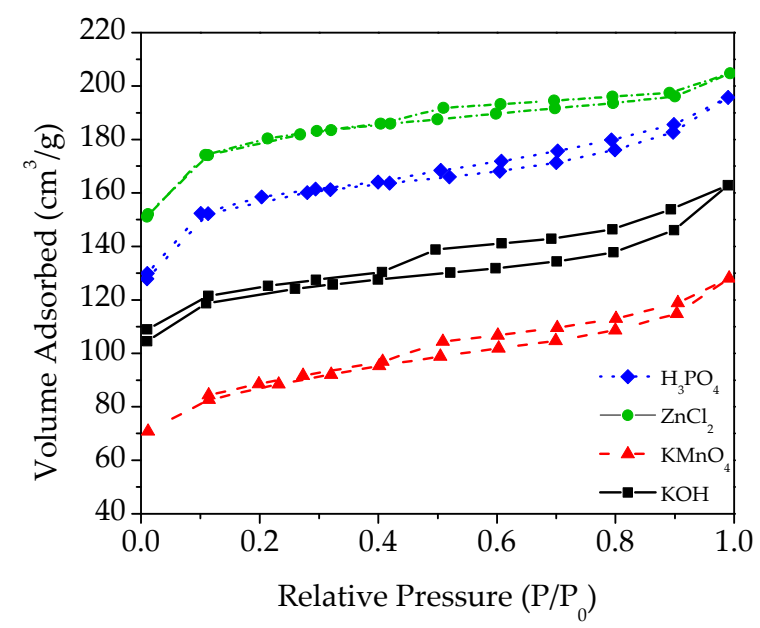

Figure 1. Effect on chemical activating agent on the adsorption-desorption isotherms of activated carbon from sago waste.

Table 1 depicts the porous properties of activated carbon from sago waste prepared using various chemical activating agents. It revealed that the mesopore volume $\left(\mathrm{V}_{\text {Mes. }}\right)$ of activated carbon prepared with base treatment $(45.7 \%$ and $37.7 \%)$ was higher than those treated with acid (33.3\% and $25.2 \%$ ). These results prove that the carbon with acid treatment contracts microporosity, while those with base treatment show mesoporosity behavior. 
However, the carbon with acid treatment has a higher total pore volume and nitrogen adsorbed compared to those with base treatment, resulting in a larger pore development due to an increase in char burn-off, confirmed by a lower yield value [3].

Table 1. Porous properties of activated carbons from sago waste prepared using various chemical activating agents.

\begin{tabular}{|c|c|c|c|c|c|c|c|}
\hline Activating & $\mathrm{V}_{\text {Mic. }}$ & $\mathrm{V}_{\text {Mes. }}$ & $\mathbf{V}_{\text {Total. }}$ & $\mathrm{V}_{\text {Mes. }} / \mathrm{V}_{\text {Mic. }}$ & Surface Area & $\begin{array}{l}\text { Average Pore } \\
\text { Diameter }\end{array}$ & Yield \\
\hline & $\left(\mathrm{cm}^{3} / \mathrm{g}\right)(\%)$ & $\left(\mathrm{cm}^{3} / \mathrm{g}\right)(\%)$ & $\left(\mathrm{cm}^{3} / \mathrm{g}\right)$ & $(\%)$ & $\left(\mathrm{m}^{2} / \mathrm{g}\right)$ & (nm) & $(\%)$ \\
\hline $\mathrm{H}_{3} \mathrm{PO}_{4}$ & $0.194(66.7)$ & $0.097(33.3)$ & 0.291 & 50.01 & 480.23 & 4.21 & 22.39 \\
\hline $\mathrm{ZnCl}_{2}$ & $0.225(74.8)$ & $0.076(25.2)$ & 0.301 & 33.78 & 546.61 & 3.32 & 23.34 \\
\hline $\mathrm{KMnO}_{4}$ & $0.152(62.3)$ & $0.092(37.7)$ & 0.244 & 60.53 & 274.92 & 4.30 & 29.98 \\
\hline $\mathrm{KOH}$ & $0.101(54.3)$ & $0.085(45.7)$ & 0.186 & 84.16 & 374.03 & 5.12 & 30.5 \\
\hline
\end{tabular}

\subsection{Structural Properties}

The structural properties of the activated carbon were examined through its crystalline structure and morphology images. Figure 2 shows the X-ray diffraction profiles of the activated carbons from sago waste prepared with various activating agents. The carbon samples demonstrated broad diffraction peaks at around $2 \theta$ of $23^{\circ}$, while those prepared with $\mathrm{KOH}$ activating agent showed slight peaks at around $2 \theta$ of $43^{\circ}$, with no sharp peaks. Furthermore, the two broad bands centered around $2 \theta$ of $23^{\circ}$ and $43^{\circ}$ were associated with the diffraction of the 002 and 100/101 planes, respectively [48]. In addition, the washing after the activation is an important process, in order to avoid residue from the activating agent solution, which prompts additional peaks [41].

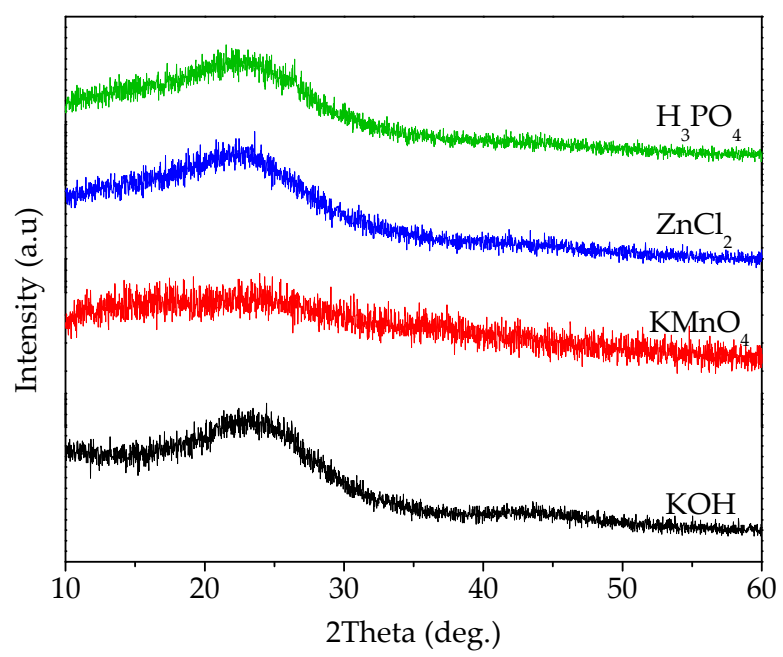

Figure 2. X-ray diffraction patterns of activated carbons from sago waste prepared using various chemical activating agents.

Figure 3 shows morphology images taken from scanning electron microscopy with $10,000 \times$ magnification. All samples show a combination of micropores and mesopores, verified the porosity properties that were previously analyzed. Figure $3 \mathrm{~b}$ shows that activated carbon from the $\mathrm{ZnCl}_{2}$ treatment has more dominant micropores, as confirmed by the lowest $\mathrm{V}_{\text {Mes. }} / \mathrm{V}_{\text {Mic. }}$ of $33.78 \%$. The mesopore is clearly seen in Figure $3 \mathrm{a}, \mathrm{c}$ as

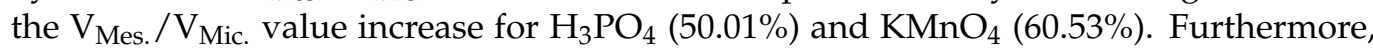
the activated carbon from the $\mathrm{KOH}$ treatment from Figure $3 \mathrm{~d}$ has more heterogeneous

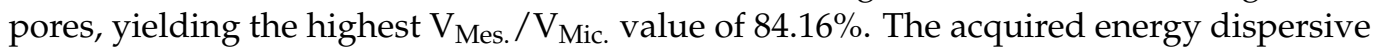
spectroscopy (EDS) provides elemental composition data for each sample, which are summarized in Table 2 . It can be seen that the elemental composition for each activator 
agent was only less than three percent, even almost undetectable for $\mathrm{KMnO}_{4}$ and $\mathrm{KOH}$. This confirmed that the sample washing process has been successful.
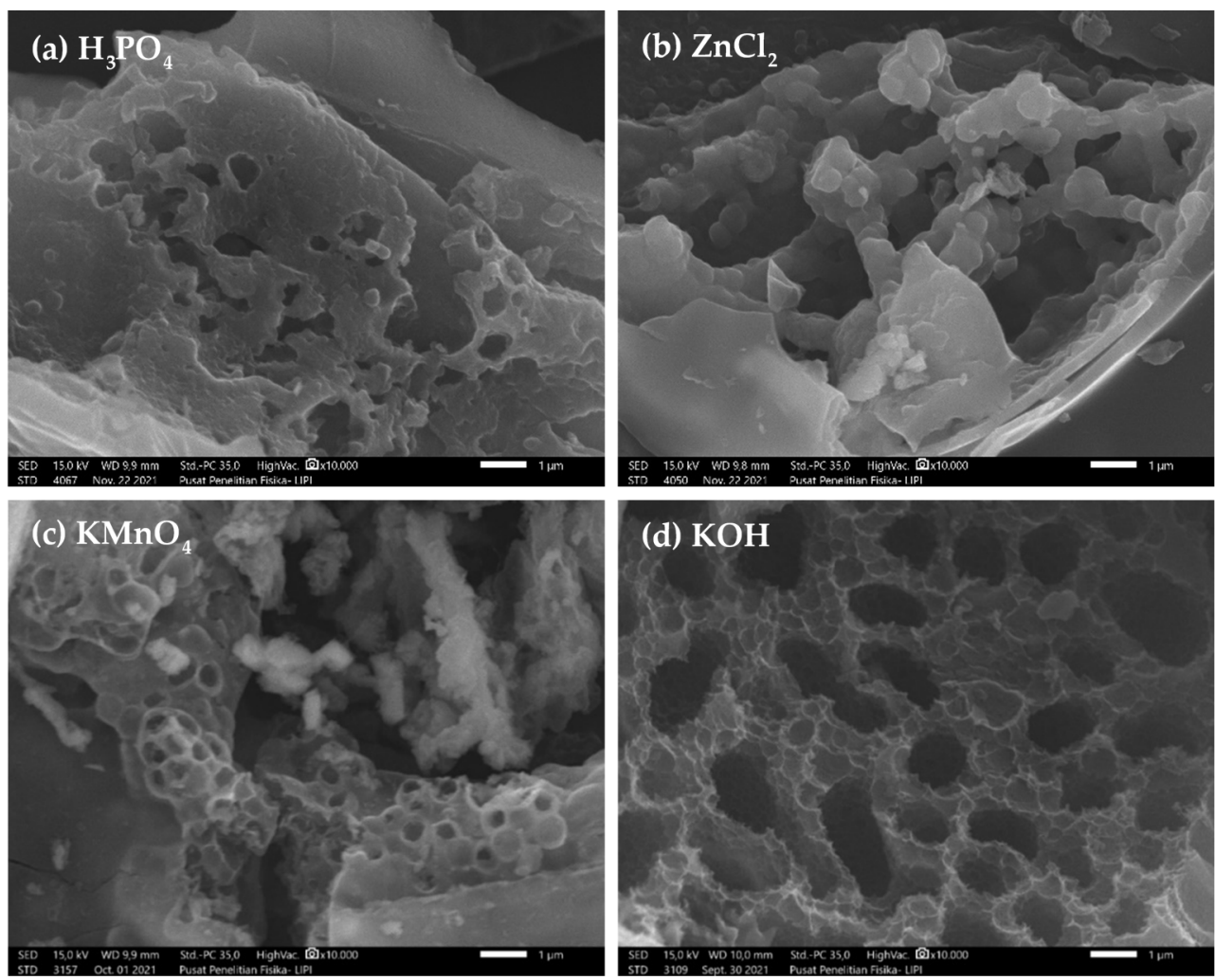

Figure 3. Scanning electron micrographs $(10,000 \times)$ of activated carbons from sago waste prepared using (a) $\mathrm{H}_{3} \mathrm{PO}_{4}$, (b) $\mathrm{ZnCl}_{2}$, (c) $\mathrm{KMnO}_{4}$, and (d) $\mathrm{KOH}$. (Bar length $=1 \mu \mathrm{m}$ ).

Table 2. Elemental composition of activated carbons from sago waste prepared using various chemical activating agents.

\begin{tabular}{ccccc}
\hline \multirow{2}{*}{ Element } & \multicolumn{4}{c}{ Mass (\%) } \\
\cline { 2 - 5 } & $\mathbf{H}_{\mathbf{3}} \mathbf{P O}_{\mathbf{4}}$ & $\mathbf{Z n C l} \mathbf{2}_{\mathbf{2}}$ & $\mathbf{K M n O}_{\mathbf{4}}$ & $\mathbf{K O H}$ \\
\hline $\mathrm{C}$ & $75.88 \pm 0.05$ & $76.52 \pm 0.03$ & $57.06 \pm 0.05$ & $81.30 \pm 0.04$ \\
$\mathrm{O}$ & $21.28 \pm 0.07$ & $21.56 \pm 0.05$ & $42.93 \pm 0.10$ & $18.70 \pm 0.07$ \\
$\mathrm{P}$ & $2.84 \pm 0.01$ & - & - & - \\
$\mathrm{Zn}$ & - & $0.09 \pm 0.00$ & - & - \\
$\mathrm{Cl}$ & - & $1.83 \pm 0.02$ & - & not detected \\
$\mathrm{K}$ & - & - & $0.01 \pm 0.01$ & - \\
$\mathrm{Mn}$ & - & - & not detected & \\
\hline
\end{tabular}

\subsection{Thermal Decomposition}

Figure 4a shows thermogravimetric curves in activated carbons from sago waste, indicating gradual mass loss during the thermal investigation. Meanwhile, Table 3 depicts the moisture, volatile matter, fixed carbon, and ash percentage in reference to the curves. The samples showed three mass loss steps, where the first step below $70{ }^{\circ} \mathrm{C}$ indicated mass losses up to $17 \%$ due to the physically adsorbed water on the material, during storage. The decomposition product of the second mass loss steps, in the period between 100 to $400{ }^{\circ} \mathrm{C}$, are assigned to the surface groups that formed during the activation process. Furthermore, the third mass loss steps at high temperatures are assigned to carbon skeleton decomposition. Rapid weight loss at temperatures of 400 to $600{ }^{\circ} \mathrm{C}$ indicated the typical activated carbon behavior, due to the formation of ash as a result of devolatilization $[49,50]$. However, the carbon prepared with $\mathrm{KOH}$ activating agent showed the lowest moisture, 
ash, and the highest fixed carbon contents of $0.92 \%, 10.90 \%$, and 43.78, respectively. The low moisture content may be the reason for the low total pore volume of the sample prepared with $\mathrm{KOH}$ [8]. In addition, the activated carbon samples prepared from $\mathrm{KOH}$ have unique decomposition profiles with intense exothermic peaks from the thermogravimetric derivative curves. This is related to organic matter thermal decomposition, which means the last mass loss step may be related to the carbon skeleton of the sample, leading to low ash content.
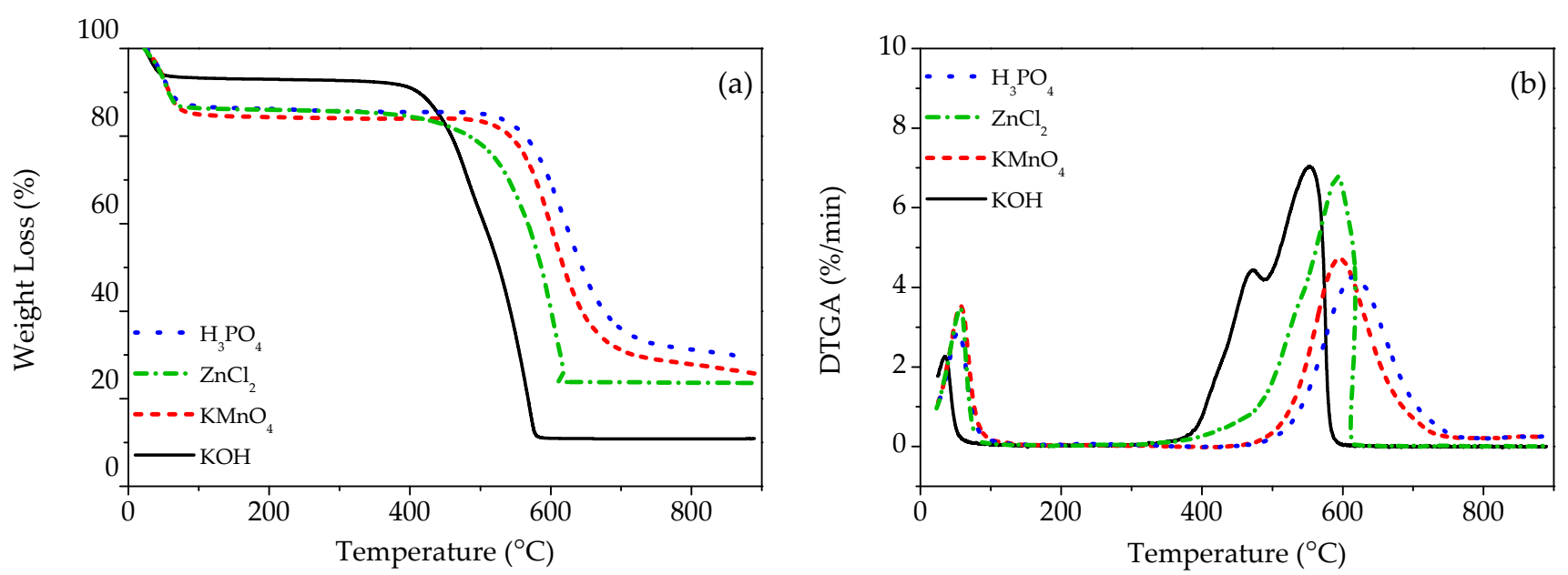

Figure 4. (a) Thermogravimetric and (b) thermogravimetric derivative curves for activated carbons from sago waste prepared using various chemical activating agents.

Table 3. Proximate analyses of activated carbons from sago waste prepared using various chemical activating agents.

\begin{tabular}{ccccc}
\hline \multirow{2}{*}{$\begin{array}{c}\text { Activating } \\
\text { Agent }\end{array}$} & \multicolumn{4}{c}{ Proximate Analysis (Weight \%) } \\
\cline { 2 - 4 } & Moisture & Volatile Matter & Fixed Carbon & Ash \\
\hline $\mathrm{H}_{3} \mathrm{PO}_{4}$ & 15.20 & 52.64 & 2.56 & 29.60 \\
$\mathrm{ZnCl}_{2}$ & 13.60 & 48.90 & 40.90 & 23.80 \\
$\mathrm{KMnO}_{4}$ & 17.04 & 42.92 & 14.02 & 26.02 \\
$\mathrm{KOH}$ & 0.92 & 44.40 & 43.78 & 10.90 \\
\hline
\end{tabular}

\subsection{Surface Groups}

Figure 5 illustrates the Fourier-transform infrared spectra of activated carbon from sago waste with various activating agents, and Table 4 shows the list of Fourier-transform infrared peaks and their assignments. There is a broad absorption around wavenumber $3650-2500 \mathrm{~cm}^{-1}$ for $\mathrm{ZnCl}_{2}$ and $\mathrm{KOH}$ activated carbon, indicating $\mathrm{O}-\mathrm{H}$ bonds. This may be due to the occurrence of phenol and carboxylate functional groups [51]. The pattern was confirmed by the presence of $\mathrm{C}-\mathrm{O}$ stretching vibration of phenol structure at $1072 \mathrm{~cm}^{-1}$, and $1135 \mathrm{~cm}^{-1}$ for $\mathrm{ZnCl}_{2}$ and $\mathrm{KOH}$ activated carbon, respectively. However, due to the absence of $\mathrm{O}-\mathrm{H}$ bonds in $\mathrm{H}_{3} \mathrm{PO}_{4}$ and $\mathrm{KMnO}_{4}$ activated carbon, the prominent band of the C-O functional group was interpreted as ether at wavenumber $1164 \mathrm{~cm}^{-1}$ and $1163 \mathrm{~cm}^{-1}$, respectively [52]. In addition, the samples exhibited a broad absorption band in the area $1555-1540 \mathrm{~cm}^{-1}$, indicating a stretching vibration of the $\mathrm{C}=\mathrm{C}$ aromatic ring structure [53]. In the fingerprint area, there were several absorption peaks assigned to $\mathrm{C}-\mathrm{H}$ bending from the alkanes group at a wavenumber less than $1000 \mathrm{~cm}^{-1}$. Furthermore, the presence of functional groups on the carbon of four different activating agents were also confirmed, this includes $\mathrm{O}-\mathrm{H}, \mathrm{C}=\mathrm{C}, \mathrm{C}-\mathrm{O}$, and $\mathrm{C}-\mathrm{H}$ groups, indicating hydroxyl, aromatic, carboxyl, and alkane, respectively [52]. 


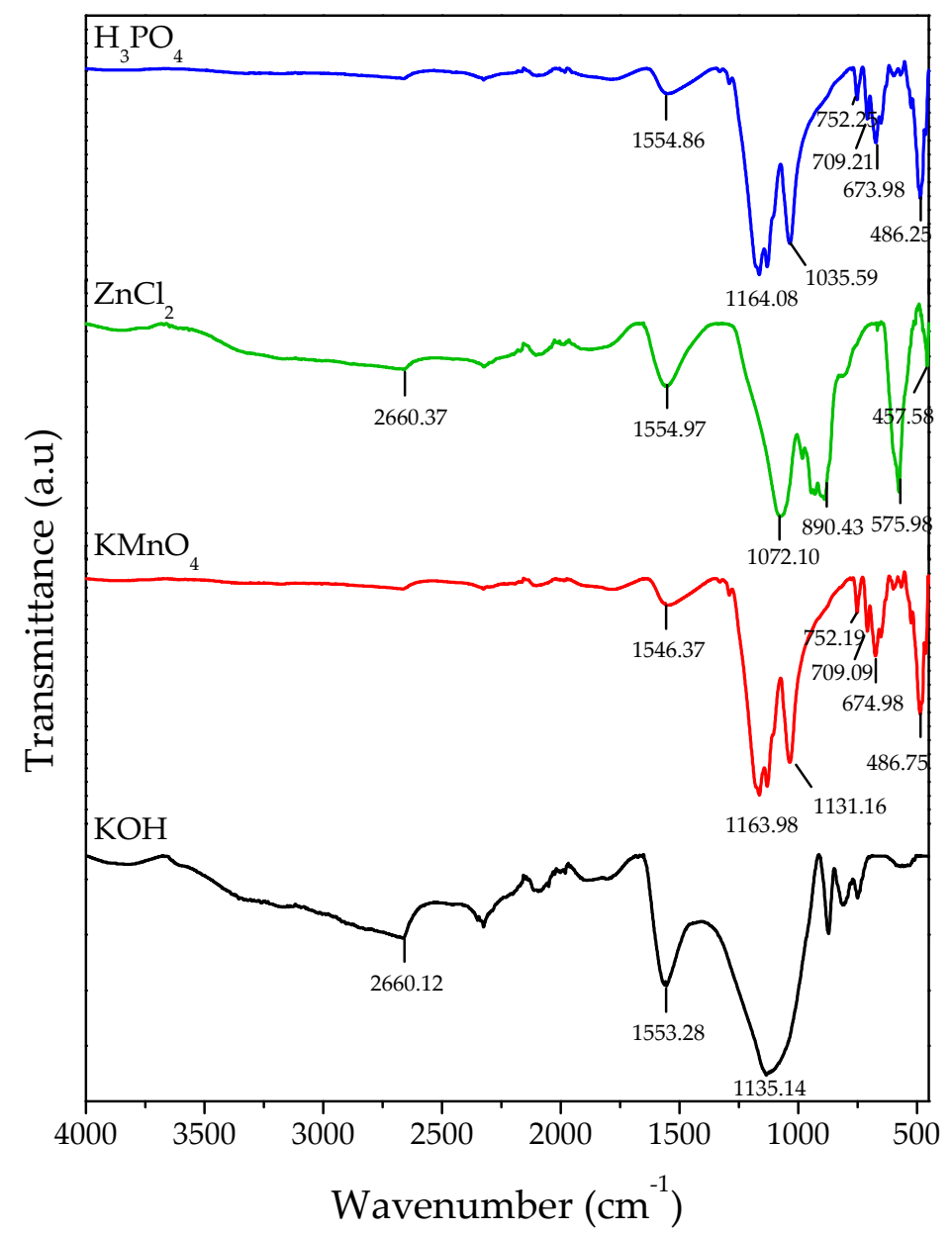

Figure 5. The Fourier-transform infrared spectra of activated carbons from sago prepared using various chemical activating agents.

Table 4. The Fourier-transform infrared peaks identification of activated carbons from sago prepared using various chemical activating agents.

\begin{tabular}{|c|c|c|c|c|}
\hline \multicolumn{4}{|c|}{ Wavenumber $\left(\mathrm{cm}^{-1}\right)$} & \multirow{2}{*}{ Assignment } \\
\hline $\mathrm{H}_{3} \mathrm{PO}_{4}$ & $\mathrm{ZnCl}_{2}$ & $\mathrm{KMnO}_{4}$ & $\mathrm{KOH}$ & \\
\hline- & 2660 & - & 2660 & $v(\mathrm{O}-\mathrm{H})$ carboxylates group \\
\hline 1554 & 1554 & 1546 & 1553 & $v(\mathrm{C}=\mathrm{C})$ aromatic group \\
\hline 1164 & - & 1163 & - & $v(\mathrm{C}-\mathrm{O})$ ether group \\
\hline- & 1072 & - & 1135 & $v(\mathrm{C}-\mathrm{O})$ phenol group \\
\hline $673 ; 486$ & $890 ; 575$ & $674 ; 486$ & - & $v(\mathrm{C}-\mathrm{H})$ akanes group \\
\hline
\end{tabular}

\section{Discussion}

There is a strong development of porosity on activation of a lignocellulosic precursor with the chemical agents [54]. Consequently, a degree of activation produces the maximum volumes of micropores, namely include $0.101,0.152,0.225$, and $0.194 \mathrm{~cm}^{3} / \mathrm{g}$ for $\mathrm{KOH}, \mathrm{KMnO}_{4}, \mathrm{ZnCl}_{2}$, and $\mathrm{H}_{3} \mathrm{PO}_{4}$, respectively. Treatment with $\mathrm{ZnCl}_{2}$ acid impregnation produces activated carbon with the highest surface area of $546.61 \mathrm{~m}^{2} / \mathrm{g}$, the strong base $\mathrm{KOH}$ successfully fabricated the fined structure and morphology, with the highest fixed carbon and the lowest ash content of $43.78 \%$ and $10.90 \%$, respectively. $\mathrm{KMnO}_{4}$ and $\mathrm{H}_{3} \mathrm{PO}_{4}$ activating agents showed poor performance with a low fixed carbon value of $2.56 \%$ and $14.02 \%$, and a high moisture content of $15.20 \%$ and $17.04 \%$, respectively.

The morphology images showed that ash was dominant over pores, and the carbon prepared from the $\mathrm{KMnO}_{4}$ activating agents had no peak in the X-ray diffraction pattern. 
Furthermore, the $\mathrm{KMnO}_{4}$ impregnation damaged the carbon structure, as indicated by the absence of the amorphous phase of carbon. This result can be confirmed from the element composition results, where $\mathrm{KMnO}_{4}$ activated carbon has a very small carbon composition of $57.06 \%$. This may yield that the $\mathrm{KMnO}_{4}$ is not effective enough to activate sago waste carbon. The surface chemistry was influenced by the chemical activating agent. Both $\mathrm{ZnCl}_{2}$ and $\mathrm{KOH}$ activated carbon revealed phenol and carboxylate groups, while the $\mathrm{H}_{3} \mathrm{PO}_{4}$ and $\mathrm{KMnO}_{4}$ showed vibration from the ether group. The carbon prepared from $\mathrm{KOH}$ also demonstrated an intense aromatic ring, due to acid washing, and thorough rinsing with distilled water [55].

The acid-activating agents tend to develop more micropore, while the base treatment develops fine mesopore-activated carbons. Generally, activated carbon has a pore structure in the form of microporous, mesoporous, and macroporous. The activated microporous carbon is more effective against pollutants in the form of gas, mesoporous carbon is effective for liquid, while macroporous carbon is not efficient for both forms [56]. The pore structure of activated carbon characteristics is highly important, it may direct potential application of activated carbon from sago waste in the future.

The commercial-grade activated carbon has a surface value between 500-1500 $\mathrm{m}^{2} / \mathrm{g}$ [57]. Thus, the highest value obtained from this study can be categorized into commercial activated carbon. Therefore, this study suggested $\mathrm{ZnCl}_{2}$ and $\mathrm{KOH}$ as suitable activators for sago waste precursor material. Further study on the effect of activation temperature and contact time on $\mathrm{ZnCl}_{2}$ and $\mathrm{KOH}$ activators may elevate the pore size of the activated carbon [55].

\section{Conclusions}

This study demonstrates the effect of chemical activating agents on the activated carbon from sago waste. This study suggests $\mathrm{ZnCl}_{2}$ and $\mathrm{KOH}$ as favorable activating agents among others. The $\mathrm{ZnCl}_{2}$ acid activating agent surpassed other chemical activators in terms of a higher specific surface area of $546.61 \mathrm{~m}^{2} / \mathrm{g}$, with a relatively high carbon content of $40.90 \%$. The micropore characteristic suggests that this material has potential gaseous pollutant adsorbent application. The base $\mathrm{KOH}$ activating agent outperformed other chemicals in terms of a mesopore carbon, with a fined structure and morphology, with the lowest ash content of $10.90 \%$. Heavy metal adsorbent from polluted liquid can be its potential application.

Author Contributions: Conceptualization, O.T., K.D. and Y.O.A.; methodology, O.T. and Y.K.A.; software, O.T.; validation, Y.K.A. and M.M.; formal analysis, M.M.; investigation, M.M.; resources, O.T.; data curation, O.T.; writing — original draft preparation, O.T., K.D. and Y.O.A.; writing-review and editing, O.T., K.D. and Y.O.A.; visualization, Y.K.A. and M.M.; supervision, O.T.; project administration, Y.K.A. and M.M.; funding acquisition, O.T. All authors have read and agreed to the published version of the manuscript.

Funding: This study was fully funded by the Ministry of Education, Culture, Research, and Technology of the Republic of Indonesia, through Prominent Fundamental Research of Higher Education (Penelitian Dasar Unggulan Perguruan Tinggi) Grant Year 2021, Contract number: 02/UN20.2.1/PG/ DRPM/2021.

Institutional Review Board Statement: Not applicable.

Informed Consent Statement: Not applicable.

Acknowledgments: The authors are grateful to the facilities, scientific and technical support from Advanced Characterization Laboratories Serpong, National Research, and Innovation Institute through E-Layanan Sains, Badan Riset dan Inovasi Nasional; Central Laboratory for Research and Services, Diponegoro University; and Biomaterial Research Laboratory, Universitas Cenderawasih.

Conflicts of Interest: The authors declare no conflict of interest. In addition, the funders had no role in the study design including collection, analyses, or data interpretation, and the writing of the manuscript, or in the decision to publish the results. 


\section{References}

1. Blankenship, T.S., II; Balahmar, N.; Mokaya, R. Oxygen-rich microporous carbons with exceptional hydrogen storage capacity. Nat. Commun. 2017, 8, 1545. [CrossRef]

2. Shafeeyan, M.S.; Daud, W.M.A.W.; Houshmand, A.; Shamiri, A. A review on surface modification of activated carbon for carbon dioxide adsorption. J. Anal. Appl. Pyrolysis. 2010, 89, 143-151. [CrossRef]

3. Lawtae, P.; Tangsathitkulchai, C. A New Approach for Controlling Mesoporosity in Activated Carbon by the Consecutive Process of Air Oxidation, Thermal Destruction of Surface Functional Groups, and Carbon Activation (the OTA Method). Molecules 2021, 26, 2758. [CrossRef]

4. Demiral, I.; Samdan, C.; Demiral, H. Enrichment of the surface functional groups of activated carbon by modification method. Surf. Interfaces. 2021, 22, 100873. [CrossRef]

5. Togibasa, T.; Ansanay, Y.O.; Dahlan, K.; Erari, M. Identification of surface functional group on activated carbon from waste sago. J. Phys. Theor-Appl. 2021, 5, 1-8. [CrossRef]

6. Li, K.; Zheng, Z.; Li, Y. Characterization and lead adsorption properties of activated carbons prepared from cotton stalk by one-step $\mathrm{H}_{3} \mathrm{PO}_{4}$ activation. J. Hazard. Mater. 2010, 181, 440-447. [CrossRef]

7. AL-Othman, Z.A.; Ali, R.; Naushad, M. Hexavalent chromium removal from aqueous medium by activated carbon prepared from peanut shell: Adsorption kinetics, equilibrium, and thermodynamic studies. Chem. Eng. J. 2012, 184, 238-247. [CrossRef]

8. Gueye, M.; Richardson, Y.; Kafack, F.T.; Blin, J. High efficiency activated carbons from African biomass residues for the removal of chromium (VI) from wastewater. J. Environ. Chem. Eng. 2014, 2, 273-281. [CrossRef]

9. Toles, C.A.; Marshall, W.E.; Johns, M.M. Granular activated carbons from nutshells for the uptake of metals and organic compounds. Carbon 1997, 35, 1407-1414. [CrossRef]

10. Liu, R.L.; Liu, Y.; Zhou, X.Y.; Zhang, Z.Q.; Zhang, J.; Dang, F.Q. Biomass-derived highly porous functional carbon fabricated by using a free-standing template for efficient removal of methylene blue. Bioresour. Technol. 2014, 154, 138-147. [CrossRef] [PubMed]

11. Mahamad, M.N.; Zaini, M.A.A.; Zakaria, Z.A. Preparation and characterization of activated carbon from pineapple waste biomass for dye removal. Int. Biodeterior. Biodegrad. 2015, 102, 274-280. [CrossRef]

12. Djeridi, W.; Ben Mansour, N.; Ouederni, A.; Llewellyn, P.L.; El Mir, L. Influence of the raw material and nickel oxide on the $\mathrm{CH}_{4}$ capture capacity behaviors of microporous carbon. Int. J. Hydrog. Energy 2015, 40, 13690-13701. [CrossRef]

13. González, A.S.; Plaza, M.G.; Rubiera, F.; Pevida, C. Sustainable biomass-based carbon adsorbents for post-combustion $\mathrm{CO}_{2}$ capture. Chem. Eng. J. 2013, 230, 456-465. [CrossRef]

14. Petkovic, L.M.; Ginosar, D.M.; Rollins, H.W.; Burch, K.C.; Deiana, C.; Silva, H.S.; Sardella, M.F.; Granados, D. Activated carbon catalysts for the production of hydrogen via the sulfur-iodine thermochemical water splitting cycle. Int. J. Hydrog. Energy 2009, 34, 4057-4064. [CrossRef]

15. Ansanay, Y.; Kolar, P.; Sharma-Shivappa, R.; Cheng, J.; Arellano, C. Pretreatment of Switchgrass for Production of Glucose via Sulfonic Acid-Impregnated Activated Carbon. Processes 2021, 9, 504. [CrossRef]

16. Sreńscek-Nazzal, J.; Kamińska, W.; Michalkiewicz, B.; Koren, Z.C. Production, characterization and methane storage potential of $\mathrm{KOH}$-activated carbon from sugarcane molasses. Ind. Crops. Prod. 2013, 47, 153-159. [CrossRef]

17. Arami-Niya, A.; Daud, W.M.A.W.; Mjalli, F.S. Using granular activated carbon prepared from oil palm shell by $\mathrm{ZnCl}_{2}$ and physical activation for methane adsorption. J. Anal. Appl. Pyrolysis. 2010, 89, 197-203. [CrossRef]

18. Liu, B.; Wang, W.; Wang, N.; Au, C.T. Preparation of activated carbon with high surface area for high-capacity methane storage. J. Energy. Chem. 2014, 23, 662-668. [CrossRef]

19. Rufford, T.E.; Hulicova-Jurcakova, D.; Zhu, Z.; Lu, G.Q. Nanoporous carbon electrode from waste coffee beans for high performance supercapacitors. Electrochem. Commun. 2008, 10, 1594-1597. [CrossRef]

20. Olivares-Marín, M.; Fernández, J.A.; Lázaro, M.J.; Fernández-González, C.; Macías-García, A.; Gómez-Serrano, V.; Stoeckli, F.; Centeno, T.A. Cherry stones as precursor of activated carbons for supercapacitors. Mater. Chem. Phys. 2009, 114, 323-327. [CrossRef]

21. Xu, B.; Chen, Y.; Wei, G.; Cao, G.; Zhang, H.; Yang, Y. Activated carbon with high capacitance prepared by NaOH activation for supercapacitors. Mater. Chem. Phys. 2010, 124, 504-509. [CrossRef]

22. González-García, P. Activated carbon from lignocellulosic precursors: A review of the synthesis methods, characterization techniques, and applications. Renew. Sustain. Energy Rev. 2018, 82, 1393-1414. [CrossRef]

23. Zhao, Y.; Fang, F.; Xiao, H.M.; Feng, Q.P.; Xiong, L.Y.; Fu, S.Y. Preparation of pore-size controllable activated carbon fibers from bamboo fibers with superior performance for xenon storage. Chem. Eng. J. 2015, 270, 528-534. [CrossRef]

24. Foo, K.Y.; Hameed, B.H. Coconut husk derived activated carbon via microwave-induced activation: Effects of activation agents, preparation parameters, and adsorption performance. Chem. Eng. J. 2012, 184, 57-65. [CrossRef]

25. Tadda, M.A.; Ahsan, A.; Shitu, A.; ElSergany, M.; Arunkumar, T.; Jose, B.; Razzaque, M.A.; Daud, N.N.N. A review on activated carbon: Process, application and prospects. J. Adv. Civ. Eng. Pract. Res. 2016, 2, 7-13.

26. Bhatnagar, A.; Hogland, W.; Marques, M.; Sillanpää, M. An overview of the modification methods of activated carbon for its water treatment applications. Chem. Eng. J. 2013, 219, 499-511. [CrossRef]

27. Ncibi, M.C.; Ranguin, R.; Pintor, M.J.; Jeanne-rose, V.; Sillanpää, M.; Gaspard, S. Preparation and characterization of chemically activated carbons derived from Mediterranean Posidonia oceanica (L.) fibres. J. Anal. Appl. Pyrolysis. 2014, 109, 205-214. [CrossRef] 
28. Galhetas, M.; Mestre, A.S.; Pinto, M.L.; Gulyurtlu, I.; Lopes, H.; Carvalho, A.P. Chars from gasification of coal and pine activated with $\mathrm{K}_{2} \mathrm{CO}_{3}$ : Acetaminophen and caffeine adsorption from aqueous solutions. J. Colloid Interface Sci. 2014, 433, 94-103. [CrossRef]

29. da Silva Lacerda, V.; López-Sotelo, J.B.; Correa-Guimarães, A.; Hernández-Navarro, S.; Sánchez-Báscones, M.; Navas-Gracia, L.M.; Martín-Ramos, P.; Martín-Gil, J. Rhodamine B removal with activated carbons obtained from lignocellulosic waste. J. Environ. Manag. 2015, 155, 67-76. [CrossRef] [PubMed]

30. Rathnayake, D.; Korotta-Gamage, S.M.; Kastl, G.; Sathasivan, A. Effect of $\mathrm{KMnO}_{4}$ treatment of granular activated carbon on the removal of natural organic matter. Desalin. Water Treat. 2017, 71, 201-206. [CrossRef]

31. Qanytah; Syamsu, K.; Fahma, F.; Pari, G. Characterization of ball-milled sago pith waste-based activated carbon treated with $\mathrm{KOH}$ and $\mathrm{KMnO}_{4}$ as activating agent. IOP Conf. Ser. Mater. Sci. Eng. 2020, 935, 012043. [CrossRef]

32. Cossarutto, L.; Zimny, T.; Kaczmarczyk, J.; Siemieniewska, T.; Bimer, J.; Weber, J.V. Transport and sorption of water vapour in activated carbons. Carbon 2001, 39, 2339-2346. [CrossRef]

33. Ramírez-Montoya, L.A.; Hernández-Montoya, V.; Montes-Morán, M.A.; Cervantes, F.J. Correlation between mesopore volume of carbon supports and the immobilization of laccase from Trametes versicolor for the decolorization of Acid Orange 7. J. Environ. Manag. 2015, 162, 206-214. [CrossRef] [PubMed]

34. Jong, F.S.; Widjono, A. Sagu: Potensi Besar Pertanian Indonesia. Iptek Tanaman Pangan. 2007, 2, 54-65. (In Indonesia)

35. Rauf, A.W.; Lestari, M.S. Pemanfaatan Komoditas Pangan Lokal Sebagai Sumber Pangan Alternatif di Papua. J. Litbang Pertan. 2009, 28, 54-62. (In Indonesia)

36. Sangadji, I.; Parakkasi, A.; Wiryawan, K.G.; Haryanto, B. Perubahan Nilai Nutrisi Ampas Sagu selam pada Fase Pertumbuhan Jamur Tiram Putih (Pleurotus ostreatus) yang berbeda. J. Ilmu Ternak. 2008, 8, 31-34. (In Bahasa Indonesia) [CrossRef]

37. Lai, J.C.; Rahman, W.A.W.A.; Toh, W.Y. Characterisation of sago pith waste and its composites. Ind. Crops Prod. 2013, 45, 319-326. [CrossRef]

38. Kadirvelu, K.; Kavipriya, M.; Karthika, C.; Vennilamani, N.; Pattabhi, S. Mercury (II) adsorption by activated carbon made from sago waste. Carbon 2004, 42, 745-752. [CrossRef]

39. Bernard, R.; Ahmed, O.H.; Majid, N.M.A. Utilization of activated carbon produced from Sago hampas (Metroxylon sagu) to reduce ammonia loss from urea. Int. J. Phys. Sci. 2011, 6, 6140-6146. [CrossRef]

40. Taer, E.; Afrianda, A.; Apriwandi; Taslim, R.; Agustino, A.; Awitdrus; Farma, R. Production of Activated Carbon Electrodes from Sago Waste and its application for an Electrochemical Double-Layer Capacitor. Int. J. Electrochem. Sci. 2018, 13, 10688-10699. [CrossRef]

41. Allo, Y.K.; Sudarmono; Togibasa, O. Synthesis and Characterization of Activated Carbon from Sago Waste (Metroxylon sagu) with $\mathrm{ZnCl}_{2}$ Activation and $\mathrm{HNO}_{3}$ Modification. J. Ind. Chem. Soc. 2019, 2, 48-53. [CrossRef]

42. Erabee, I.K.; Ahsan, A.; Nik Daud, N.N.; Idrus, S.; Shams, S.; Md Din, M.F.; Rezania, S. Manufacture of low-cost activated carbon using sago palm bark and date pits by physiochemical activation. BioRes 2017, 12, 1916-1923. [CrossRef]

43. Erabee, I.K.; Ahsan, A.; Zularisam, A.W.; Idrus, S.; Daud, N.N.N.; Arunkumar, T.; Sathyamurthy, R.; Eid Al-Rawajfeh, A. A New Activated Carbon Prepared from Sago Palm Bark through Physiochemical Activated Process with Zinc Chloride. Eng. J. 2017, 21, 1-14. [CrossRef]

44. Dahlan, N.A.; Ng, S.L.; Pushpamalar, J. Adsorption of methylene blue onto powdered activated carbon immobilized in a carboxymethyl sago pulp hydrogel. J. Appl. Polym. Sci. 2016, 134, 44271. [CrossRef]

45. Demiral, İ.; Aydın Şamdan, C.; Demiral, H. Production and characterization of activated carbons from pumpkin seed shell by chemical activation with $\mathrm{ZnCl}_{2}$. Desalin. Water Treat. 2015, 57, 2446-2454. [CrossRef]

46. Mistar, E.M.; Alfatah, T.; Supardan, M.D. Synthesis and characterization of activated carbon from Bambusa vulgaris striata using two-step KOH activation. J. Mater. Res. Technol. 2020, 9, 6278-6286. [CrossRef]

47. Sing, K.S.W.; Williams, R.T. Physisorption hysteresis loops and the characterization of nonporous materials. Adsorpt. Sci. Technol. 2004, 22, 773-782. [CrossRef]

48. Girgis, B.S.; Temerk, Y.M.; Gadelrab, M.M.; Abdullah, I.D. X-ray Diffraction Patterns of Activated Carbons Prepared under Various Conditions. Carbon Lett. 2007, 8, 95-100. [CrossRef]

49. Suhdi; Wang, S.-C. Fine Activated Carbon from Rubber Fruit Shell Prepared by Using $\mathrm{ZnCl}_{2}$ and $\mathrm{KOH}$ Activation. Appl. Sci. 2021, 11, 3994. [CrossRef]

50. Craik, S.A.; Gray, M.R.; Hrudey, S.E.; Fedorak, P.M. Thermogravtmetric determination of biomass on activated carbon. Environ. Technol. 1991, 12, 489-496. [CrossRef]

51. Dabrowski, A.; Podkościelny, P.; Hubicki, Z.; Barczak, M. Adsorption of phenolic compounds by activated carbon-A critical review. Chemosphere 2005, 58, 1049-1070. [CrossRef]

52. Jurgis, B.; Maryte, D. Investigation of the functional groups on the surface of activated carbons. J. Serb. Chem. Soc. 2004, 69, 363-375. [CrossRef]

53. Paredes-Doig, A.L.; Sun-Kou, M.D.R.; Picasso-Escobar, G.; Cannata, J.L. A Study of the Adsorption of Aromatic Compounds Using Activated Carbons Prepared from Chestnut Shell. Adsorpt. Sci. Technol. 2014, 32, 165-180. [CrossRef]

54. Molina-Sabio, M.; Rodríguez-Reinoso, F. Role of chemical activation in the development of carbon porosity. Colloids Surf. A Physicochem. Eng. Asp. 2004, 241, 15-25. [CrossRef]

55. Lua, A.C.; Yang, T. Effect of activation temperature on the textural and chemical properties of potassium hydroxide activated carbon prepared from pistachio-nut shell. J. Colloid Interface Sci. 2004, 274, 594-601. [CrossRef] [PubMed] 
56. Danish, M.; Ahmad, T. A review on utilization of wood biomass as a sustainable precursor for activated carbon production and application. Renew. Sustain. Energy Rev. 2018, 87, 1-21. [CrossRef]

57. Saleem, J.; Shahid, U.; Hijab, M.; Mackey, H.; McKay, G. Production and applications of activated carbons as adsorbents from olive stones. Biomass Conv. Bioref. 2019, 9, 775-802. [CrossRef] 